\title{
SUSTAINABILITY CONSIDERATIONS IN BIOFUEL DEVELOPMENT IN SASKATCHEWAN, CANADA
}

\author{
S. N. KULSHRESHTHA \& E. MUSABA \\ University of Saskatchewan, Canada
}

\begin{abstract}
With the last round of negotiations under the Paris Conference of the Parties (COP) now completed, every country would be searching for avenues to meet the targets agreed upon in the COP. Among various options, biofuel development has historically been a preferred option in various countries and Canada (including Saskatchewan) is no exception to it. One of the major motivations of this development is to help the rural communities grow. Results of this study suggest that smaller rural economies in Saskatchewan do not grow under such an initiative, since they have a large degree of leakages. Thus, biofuel development helps more to larger nearby communities than smaller communities. Another aspect of rural development is increased farm level incomes. Both ethanol and biodiesel production activities indicate a favorable impact on farm net income in Saskatchewan. However, in order to develop sustainable biofuel program, some attention needs to be paid to other aspects. Included here are implications of such a development on greenhouse gas (GHG) emissions and land use changes, water use, subsidization and further stress on international food security. On the water use issue, examination needs to be made both for the feedstock used and production of biofuel. If the feedstock is through irrigated production, biofuel's desirability on this count is reduced. Estimated GHG emissions from biofuel production studied in a life cycle assessment format, suggest a major reduction is possible, although they are slightly lower if the production of feedstock affects land use changes. Although the issue of food security in the context of Saskatchewan or Canada has not been raised, internationally such concerns could arise depending on the scale of expansion of such production in various countries. Keywords: biofuel, greenhouse gas emissions, saskatchewan, sustainable, water use.
\end{abstract}

\section{INTRODUCTION}

A biofuel is a fuel that is produced through contemporary biological processes, such as agriculture and anaerobic digestion. This is different from that produced by geological processes creating fossil fuels, such as coal and petroleum, from prehistoric biological matter. Two of the most commonly used biofuels are bioethanol (or simply ethanol) and biodiesel, both of which are used primarily as additives in vehicles used for transportation purposes.

Concerns over the global warming have been rising, as the FCCC [1] noted 'climate change represents an urgent and potentially irreversible threat to human societies and the planet and thus requires the widest possible cooperation by all countries, with a view to accelerating the reduction of global greenhouse gas emissions'. Although no specific greenhouse gas (GHG) targets were agreed upon at this Paris Conference of the Parties (COP), the strong need for reducing such emissions over the next few decades is acknowledged. Recent drop in oil process has also meant some slowdown in the production of ethanol, which has not helped the reduction of GHG emissions for Saskatchewan (or even Canada). However, some see such a development only a temporary situation. 
Two main national issues in Canada are falling farming incomes, and global climate change. Solutions that address both of these issues are preferred for further action. Biofuel development is seen to help improve both of these issues. However, there is a need for investigating the total GHG emissions using a life cycle analysis framework. Furthermore, biofuel production can also have an impact on resource use, particularly water resources. When one looks at the biofuel from a sustainability perspective a number of issues arise, including its subsidization, effect on food security from a global perspective, among others. In this paper, these issues are explored further.

\section{LINKS BETWEEN BIOFUEL DEVELOPMENT AND RURAL COMMUNITIES}

In addition to reduced GHG emissions, both ethanol and biodiesel are promoted based on their linkages with rural communities. In both cases, the connection is through expanding markets for the products grown. Saskatchewan is a major grain producing region and is called 'bread basket' of Canada. Much of its production is destined for exports. Over the 2005-2006 to 2010 2011, about $68 \%$ of the wheat produced in Canada was destined for exports (Based on data provided by [2]). These international markets are highly variable, and demand level fluctuates from time to time. Creation of stable domestic outlets for crops has two benefits for producers: One, it reduces their dependence on the more volatile export markets and brings some stability for the sector; and Two, since products are not transported a long distance (farm to the export points), the farm level price increases, along with a reduction in Canadian GHG emissions.

\section{IMPACT OF BIOFUEL DEVELOPMENT ON RURAL ECONOMIES}

\subsection{Ethanol production}

Impact of ethanol production on a rural community depends on its size (measured as population base). Population is directly related to the availability of goods and services. Although some inputs are supplied locally, not all inputs are available in all rural communities, which results in a large degree of leakages.

To estimate the economic impacts of this plant on various types of communities, they were divided into seven categories: (1) Rest of Saskatchewan (ROS) communities not classified under any other class; (2) Minimum convenience centers (MCC); (3) Full convenience centers (FCC); (4) Partial shopping centers (PSC); (5) Complete shopping centers (CSC); (6) Secondary wholesale retail center (SWR); and (7) Primary wholesale retail center (PWR). This classification is based on the availability of services in each center. Number of services and population of these communities are shown in Table 1.

The ROS region is an open countryside area and does not have any services. Much of the economic activity is related to agriculture, forestry, hunting, mining, and fishing. Residents here go to other six types of communities to obtain their needed goods and services. The MCC community would have fewer services which would include mostly those used by local resident on a regular basis. Typically, there would be four types of services enjoyed by an average 160 people residing therein. As one moves up to other community types, the number of services increase, with PWR providing all services offered by any other category of communities. These communities also serve a larger population base.

In the study, an integrated Ethanol-Cattle Feeding Production (ECFP) complex was designed and located in different size communities [3]. The byproducts of ethanol produc- 
Table 1: Descriptive measures of community types.

\begin{tabular}{lccc}
$\begin{array}{l}\text { Community } \\
\text { type }\end{array}$ & $\begin{array}{l}\text { No. of communities } \\
\text { in Saskatchewan }\end{array}$ & $\begin{array}{l}\text { Average population } \\
\text { in 2001 }\end{array}$ & $\begin{array}{l}\text { Average no. of services } \\
\text { per community }\end{array}$ \\
\hline ROS & 326 & $*$ & $-* *$ \\
MCC & 306 & 160 & 4 \\
FCC & 113 & 1,082 & 21 \\
PSC & 50 & 2,230 & 70 \\
CSC & 6 & 4,360 & 196 \\
SWR & 8 & 18,360 & 533 \\
PWR & 2 & 187,000 & 4,213 \\
Total & 811 & - & \\
\hline
\end{tabular}

*Population count for these communities lies somewhere between that of MCC and FCC.

**Open areas with agriculture, hunting, mining, fishing and forestry operations. Source: Average population estimated from [4].

tion, dried distillers grains with solubles (DDGS), were used for the cattle production. The capacity of the ethanol plant was 15 million liters per year, and the feedlot has 100 head of cattle. Estimation of economic impacts of the ECFP complex was done using a hierarchical seven region input-output model. These regions are the same as listed in Table 1. Each of these models contained 14 economic sectors, with one of them for the ethanol-feedlot and two sectors for the production of wheat and for cattle. Regional leakages were estimated using employment data. A survey of consumers in various communities was also conducted to note their shopping patterns and thereby leakages at the consumption level.

Economic impacts of ECFP complex were estimated separately for two phases of development: (1) construction phase and (2) operations phase. Plant was built in each of the first six regions; the seventh region (ROS), being open country side, was not selected as it has no non-agricultural activities. However, the products needed for the complex are supplied by this region.

\subsubsection{Construction phase impacts}

Many of the inputs required during the construction phase for the complex are obtained from outside of the province (other parts of Canada or from the Rest of the World). As shown in Fig. 1, almost two-thirds of total outlay is on products imported. Even for the intermediate inputs, if these are not available in the designated community, they are imported from other communities in the province.

Since almost two-thirds of expenditures during the construction phase are leaked out (obtained from outside the province), the Type II (direct, indirect and induced) income multiplier for the province as a whole was only 0.122 . How this income is distributed among the seven types of communities differently when a plant is located in a given community, as shown in Table 2. If the plant is located in a MCC or FCC (smaller population communities) type community, only $3.3 \%$ of the total income is retained by the local communities. The 


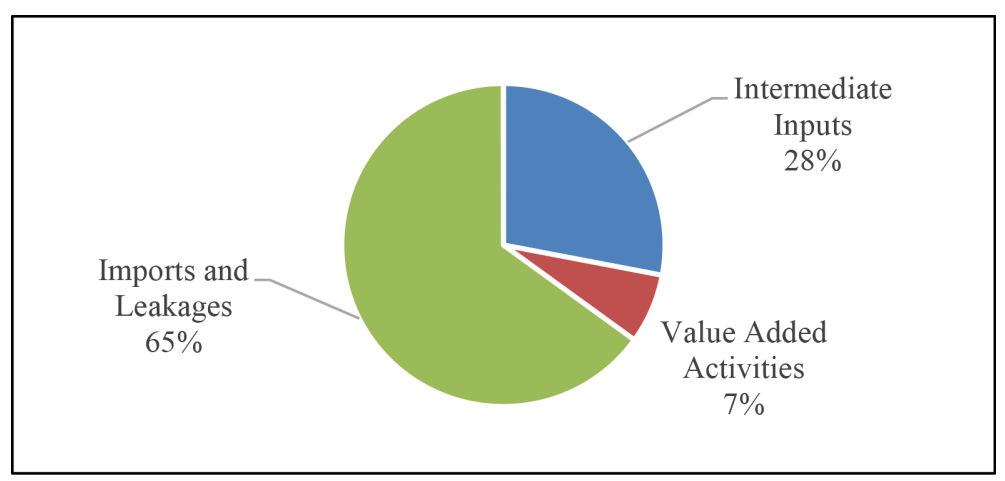

Figure 1: Distribution of direct expenditures for construction of the ECFP complex.

Table 2: Share of different types of communities of the total provincial income generated during construction phase of the ECFP complex.

\begin{tabular}{lllllll}
\hline & \multicolumn{6}{c}{ Plant location } \\
\cline { 2 - 7 } Impact region & PWR\% & SWR \% & CSC \% & PSC \% & FCC \% & MCC \% \\
\hline PWR & 88.5 & 6.6 & 63.1 & 63.9 & 88.5 & 88.5 \\
SWR & 1.6 & 72.1 & 9.8 & 9.8 & 1.6 & 1.6 \\
CSC & 0.0 & 0.0 & 11.5 & 5.7 & 0.0 & 0.0 \\
PSC & 0.8 & 2.5 & 0.8 & 5.7 & 0.8 & 0.8 \\
FCC & 0.8 & 1.6 & 1.6 & 1.6 & 0.8 & 0.8 \\
MCC & 3.3 & 3.3 & 4.1 & 3.3 & 3.3 & 3.3 \\
ROS & 4.9 & 14.8 & 9.0 & 9.8 & 4.9 & 4.9 \\
Province & 100.0 & 100.8 & 100.0 & 100.0 & 100.0 & 100.0 \\
\hline
\end{tabular}

Source: Estimated using data from [3].

larger community, such as the PWR, receives the largest share of the total income. This distribution does not change significantly for the CSC and PSC type communities.

Output multipliers were estimated for each of the six types of community (Table 3). On account of a large volume of imported goods, even for the larger community (PWR), the change in its output is only 0.414 . Thus of the one dollar spent during the construction phase of the ECFP complex, only 41 cents are retained in the community itself.

As one goes down the hierarchy, this multiplier becomes smaller and smaller, and is only 0.001 for the MCC type community. Thus, most of the economic activity is created in large urban centers since most of the input requirements for the complex are available only in these types of communities. Effect of the construction activities related to the complex on smaller communities thus, is very small. It should be noted that these impacts are short-lived. 
Table 3: Output multipliers for construction scenario for the ECFP complex.

\begin{tabular}{lcc}
\hline Location of complex & Construction phase multiplier & Operations phase multiplier \\
\hline PWR & 0.414 & 1.46 \\
SWR & 0.390 & 1.31 \\
CSC & 0.071 & 1.10 \\
PSC & 0.032 & 1.10 \\
FCC & 0.002 & 1.03 \\
MCC & 0.001 & 1.02 \\
\hline
\end{tabular}

Table 4: Share of different types of communities in the total incomes generated during the Operations phase of the ECFP complex.

\begin{tabular}{lcccccr}
\hline & \multicolumn{6}{c}{ Plant location } \\
\cline { 2 - 7 } Impact region & PWR \% & SWR \% & CSC \% & PSC \% & FCC \% & MCC \% \\
\hline PWR & 65.5 & 17.2 & 34.5 & 34.5 & 41.4 & 44.8 \\
SWR & 3.4 & 48.3 & 3.4 & 3.4 & 3.4 & 3.4 \\
CSC & 0.0 & 0.0 & 27.6 & 0.0 & 0.0 & 0.0 \\
PSC & 0.0 & 3.4 & 0.0 & 27.6 & 0.0 & 0.0 \\
FCC & 0.0 & 0.0 & 0.0 & 0.0 & 24.1 & 0.0 \\
MCC & 3.4 & 3.4 & 3.4 & 3.4 & 3.4 & 24.1 \\
ROS & 27.6 & 27.6 & 31.0 & 31.0 & 27.6 & 27.6 \\
Province & 100.0 & 100.0 & 100.0 & 100.0 & 100.0 & 100.0 \\
\hline
\end{tabular}

\subsubsection{Operations phase impacts}

During the operational phase of the ECFP complex, sales of ethanol, and cattle (plus manure from the feedlot) creates economic impacts on the community. Economic impacts during the operation phase are created through the production of inputs required by the ECFP, such as cereals, cattle, feed grains, straw, among others, which are supplied by the ROS type region. Plants located in other types of communities produce ethanol by importing needed inputs not available locally. If a plant is located in a smaller community type (such as a MCC or FCC), through providing agricultural inputs, the ROS region community receives about $28 \%$ of the total income generated, and the larger community such as the PWR or SWR almost half $(48 \%)$ of the total income. The community where the plant is located receives only a quarter of the provincial income generated by the ECFP complex (Table 4). The share of total provincial income received by the community where the complex is located increases as the size of the community increases (Fig. 2).

\subsection{Biodiesel production}

Saskatchewan has a single biodiesel plant in operations. It has one unique feature - it uses weather-damaged canola seeds. These seeds have no commercial market on account of low 


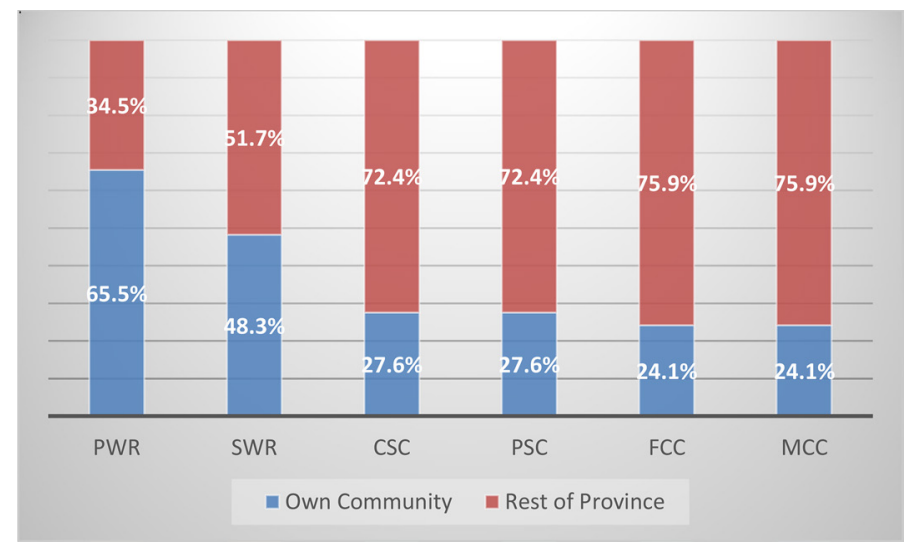

Figure 2: Share of total income generated during operations phase in the community with the ECFP complex.

oil contents. Use of these types of seed for biodiesel production results in new market opportunity for the producers, and increases their incomes. Another advantage of a biodiesel plant of this type is that the low quality canola seeds would return a positive contribution to the processing firm even at a crude oil price of $\$ 70$ per barrel, whereas the same with high-quality seed would require a price of $\$ 95$ per barrel [5]. Biodiesel production, from either soybean or canola oil, results in a positive energy balance [6] and reduced GHG emissions.

\section{ETHANOL DEVELOPMENT AND GREENHOUSE GAS EMISSIONS}

For producing ethanol in Saskatchewan (or any other prairie province), two types of feed stocks, besides cereals, could be used to reduce GHG emissions: One, utilization of crop residues; and Two, use of warm (switchgrass) and cool (Mammoth wildrye) season grasses [7]. The results were reported in terms of net farm margins, land use changes, and reduction in GHG emissions. For the farm level GHG accounting, the Canadian Economic and Emissions Model for Agriculture (CEEMA) was utilized. This model is based on a life cycle analysis type framework as it takes into account all activities from the seed to final disposition of the needed input for ethanol production. In addition to the farm level and agriculturally related GHG emissions, other GHG emissions included those from manufacturing of ethanol, as well as from the use blended gasoline production in transportation vehicles.

\subsection{Farm net margins}

Use of crop residues included straw from cereal grains (wheat, barley and oats). Only the excess straw was used for ethanol production since part of the straw is needed to be retained for reducing soil erosion. This scenario did not produce any land use changes, since no new crops were introduced. Total net farm margins increased 4.3\% in Alberta, 2.1\% in Saskatchewan, and by $5.3 \%$ in Manitoba, for the change at the Prairie level of $3.2 \%$.

Under growing of warm and cold season grasses and using them for biofuel production yielded positive net farm margin for crop producers but decreased that for the livestock producers. Overall increase in the farm margins for the prairies was 3.5\% with Alberta leading 
at $+11.2 \%$, but Saskatchewan producers having a net loss of $1.1 \%$. For the prairie region as a whole, crop producers increased their margins by $3.5 \%$, but the livestock producers lost net farm revenue by an average of $21.4 \%$. Saskatchewan was the leader in the loss of $36.8 \%$ under this scenario. Combining both crops and livestock production activities, prairies as a whole lose $3.7 \%$ of their net farm margin under the production of warm and cool season crops.

\subsection{Greenhouse gas emissions}

One of the aspect that is critical in evaluating sustainability of biofuel production is full accounting of their carbon contents [8]. GHG emissions in this study [7], were a sum of three major gases: carbon dioxide, methane and nitrous oxide. These emissions were first measured for the agriculture production, then at the agriculture and agri-food sector, and then for the entire biofuel complex. Results are shown in Table 5.

Since each of the GHGs has a different impact on the climate, convention is to convert them in terms of carbon dioxide. This measure is called carbon dioxide equivalent $\left(\right.$ or $\left.\mathrm{CO}_{2 \mathrm{e}}\right)$. Under the use of agricultural byproducts (straw) scenario, farm level GHG emissions are reduced by 461 kilotonnes (thousand tonnes), but due to other activities involved this reduction is lowered to 438 kilotonnes for the entire agriculture and agri-food sector. This sector includes, in addition to farm level production, off-farm emissions from transportation and storage, indirect emissions, and ecosystem level emissions. Adding the production of ethanol and its use in transportation, reduced the total emissions to $10 \mathrm{MT}$ (mega tonnes), or 6,474 per million liter of fuel used. Thus, using straw and other byproducts from agriculture is preferred if the objective is to reduce GHG emissions from agriculture.

Table 5: Change in the GHG emissions from biofuel production and use, Prairie region.

\begin{tabular}{|c|c|c|c|c|}
\hline \multirow[b]{3}{*}{ GHG accounting level } & \multicolumn{4}{|c|}{ Change in level from in $\mathrm{CO}_{2 \mathrm{e}}$ basis (tonnes) } \\
\hline & \multicolumn{2}{|c|}{ Scenario agricultural biomass } & \multicolumn{2}{|c|}{$\begin{array}{c}\text { Scenario warm and cool season } \\
\text { crops }\end{array}$} \\
\hline & Total quantity & $\begin{array}{c}\text { Per million liters } \\
\text { of biofuel }\end{array}$ & Total quantity & $\begin{array}{c}\text { Per million } \\
\text { liters of biofuel }\end{array}$ \\
\hline Farm level production & $-461,000$ & -297.6 & $+334,000$ & +161.9 \\
\hline $\begin{array}{l}\text { Agriculture and agri- } \\
\text { food sector }\end{array}$ & $-438,000$ & -282.8 & $+33,000$ & +16.0 \\
\hline $\begin{array}{l}\text { Biofuel production } \\
\text { and use }\end{array}$ & $-6,110,000$ & $-3,944.5$ & $-2,737,000$ & $-1,326.7$ \\
\hline Blended fuel use & $-3,480,000$ & $-2,246.6$ & $-4,640,000$ & $-2,246.6$ \\
\hline Total & $-10,028,000$ & $-6,473.8$ & $-7,344,000$ & $-3,559.9$ \\
\hline
\end{tabular}

Source: Estimated using data provided by [7]. 
When ethanol is produced from warm and cool season grasses, GHG emissions are generated through an additional source - land use changes. Since land area is fixed, adding other crops can only be done by replacing the current crops by the new crops needed for ethanol production. This increases both farm level and agriculture and agri-food level GHG emissions. However, when ethanol production and use are included, the use of these feedstock reduces 3.6 MT of GHG emissions.

Based on these results, use of byproducts from agriculture seems like a better choice for ethanol production. Furthermore, use of cool and warm season crops requires development of different manufacturing methods (cellulogic) which are still in development stage.

\section{OTHER CONSIDERATIONS FOR SUSTAINABLE BIOFUEL DEVELOPMENT}

Biofuel production, in addition to net farm income and GHG emissions mitigation, can also be preferred on other grounds. For example, it can bring some relief to a region from a narrow concentrated network of extraction, refining, and distribution [3]. Biofuel production is less concentrated on account of a large land-based requirement and therefore, does not require elaborate distribution system for domestic use. However, if much of is demand is in other regions, some cheaper form of transportation would still be needed.

In the context of rural development, biofuel can also contribute in other ways, as shown in Table 6. Besides local job creation and infusion of additional cash through wages and retained earnings, it can have some beneficial effects on human health, and through that on quality of life.

Some economic benefits from biofuel production must be considered against the public support that is needed for their development. Currently such production requires some government support. But to be fair, comparison should be with the oil industry which also requires some subsidization. However, provision of large subsidies to encourage large ethanol production distort agricultural markets and food prices in Canada and elsewhere [11]. Market effects of biofuel expansion can also be significant. Price for feedstock may rise since its demand has increased, which are beneficial to producers but not to the consumer and international trade. For the world as a whole, there may be implications for food security, as world food deficit would increase from 420 million tonnes to 680 million tonnes - an increase of $62 \%$ (Table 7). For already food deficit countries, this would increase the number of undernourished people.

Another positive feature of production of biofuel is that related to local availability of coproducts. For example, DDGS is a high-protein residual from ethanol production. Such products may induce further livestock (cows and pigs) feeding activity in the vicinity of ethanol plants, creating additional employment.

Non-market ecosystem services are important to society. Such services are unpriced in a typical market place. However, on account of land use changes, land base fuel production systems speed up deforestation and causes substantial carbon emissions due to conversion of forests into agricultural lands.

Water requirements of an ethanol plant are also large. A 50 Mmgy plant would require 150-300 million gallons of water [13]. Thus, water requirements are 3-6 times the final product. The upper limit of this use is due to use of irrigated crops as feedstock. If feedstock is from dryland agriculture, water use is around three times. Some communities may not have sufficient infrastructure to provide this quantity of water.

\section{CONCLUSIONS}

In conclusion, this study concludes that biofuel production is not a good strategy for developing small-sized communities. However, for agricultural producers this development provides 
Table 6: Various rural development aspects associated with biofuel production.

\begin{tabular}{lcc}
\hline Aspects of rural development & Direct relationship & Indirect relationship \\
\hline Local job creation & $\mathrm{X}$ & \\
Higher level income & & \\
Better energy services & $\mathrm{X}$ & \\
Improved local health & $\mathrm{X}$ & $\mathrm{X}$ \\
Good infrastructure facilities & & $\mathrm{X}$ \\
Improved knowledge and skills & & $\mathrm{X}$ \\
High productivity & & \\
Quality of life & $\mathrm{X}$ & \\
Stabilized local economy & & \\
\hline
\end{tabular}

Source: [10].

Table 7: Implications of biofuel production on world food deficit in thousand tonnes.

\begin{tabular}{lcccccc}
\hline & \multicolumn{2}{c}{2020} & \multicolumn{2}{c}{2050} & \multicolumn{2}{c}{2080} \\
\cline { 2 - 7 } Region & $\begin{array}{c}\text { Low } \\
\text { Impact }\end{array}$ & $\begin{array}{c}\text { High } \\
\text { Impact }\end{array}$ & $\begin{array}{c}\text { Low } \\
\text { Impact }\end{array}$ & $\begin{array}{c}\text { High } \\
\text { Impact }\end{array}$ & $\begin{array}{c}\text { Low } \\
\text { Impact }\end{array}$ & $\begin{array}{c}\text { High } \\
\text { Impact }\end{array}$ \\
\hline Developed countries & 60 & -20 & 120 & -65 & 85 & -175 \\
Developing countries & 30 & -30 & 55 & -115 & -10 & -250 \\
World & 75 & -40 & 140 & -155 & 65 & -420 \\
World with biofuels & -105 & -120 & -100 & -415 & -175 & -680 \\
\hline
\end{tabular}

Source: [12].

new markets, and reduced their dependence on export trade. Since these communities do not have all the intermediate inputs, much of the expenditures are leaked out to larger population centers, which benefits the large communities more than the smaller ones.

It is also emphasized that the modern bioenergy will certainly make a meaningful strategy, although it is not the only solution, to address energy and development problems of rural regions. Comparison of costs and benefits of biofuel projects against those from other alternative means of improving rural areas need to be considered as an important pre-requisite to their development. Although subsidies can be defended as payment to non-market good ad services, a critical examination of such program is needed. Identification of non-market goods provided by biofuel production and use has not been addressed.

Impact of land use changes, resulting in higher GHG emissions, may be minimized developing technologies to improve the efficiency of conversion of biomass to biofuels. This not only improves the energy yield of biofuels but also reduces the overall environmental costs and economic burden on the society, and hopefully could provide sufficient quantity to satisfy the energy needs of the society. 


\section{REFERENCES}

[1] FCCC (Framework Convention on Climate Change), Adoption of the Paris Agreement. Conference of the Parties, Paris, 30 November 2015 to 11 December 2015.

[2] Statistics Canada, Cereals and Oilseed Review, available at: http://www.statcan.gc.ca/ pub/22-007-x/2012004/t047-eng.htm, (accessed 29 January 2016).

[3] Musaba, E., Spatial diffusion of economic integrated ethanol-cattle production complex in Saskatchewan. Unpublished Ph.D. Thesis, University of Saskatchewan, Saskatoon, 1997.

[4] Stabler, J. \& Olfert, R., Saskatchewan's Communities in the Twenty-first Century. Canadian Plains Research Center: Regina, 2002.

[5] Nagy, C. \& Furtan, H., Economic assessment of biodiesel in Saskatchewan. Unpublished document, University of Saskatchewan, Saskatoon, 2006.

[6] Smith, E., Janzen, H. \& Newlands, N., Energy balances of biodiesel production from soybean and canola in Canada. Canadian Journal of Plant Sciences, 87, pp. 793-801, 2007. http://dx.doi.org/10.4141/CJPS06067

[7] Seecharan, R., Ravindrapal, G., Kulshreshtha, S., Junkins, B. \& Bussler, O., Expanded use of biofuels: economics and greenhouse gas emissions related implications for the agriculture sector. World Economic Review, 14(2), pp. 204-221, 2002.

[8] Marshall, L., Carving out policy space for sustainability in biofuel production. Agricultural and Resource Economics Review, 36(2), pp. 183-196. 2007.

[9] World Watch Institute, Biofuels for Transport, Earthcan: London, 2007.

[10] Sheelanere, P. \& Kulshreshtha, S., Sustainable biofuel production: opportunities for rural development. International Journal of Environment and Resources, 2(1), pp. 1-13, 2013.

[11] Auld, D., The Ethanol Trap: Why Policies to Promote Ethanol as Fuel Need Rethinking. C.D. Howe Institute: Ottawa, 2008.

[12] IIASA (International Institute for Applied Systems Analysis), Biofuels and climate change: challenge to food security in the twenty-first century. Options, Winter, ,pp. 18-19, 2009/10.

[13] Stanich, T., Water efficiency as a result of sound water management. available at: www. ethanolproducer.com/articles/2740/water-efficiency-as-a-result-of-sound-water-management/, 2016 (accessed 29 January 2016). 